\title{
BEHAVIORAL FINANCE IN THE ERA OF COVID-19
}

\section{DOI: 10.17261/Pressacademia.2021.1496 \\ PAP- V.14-2021(22)-p.106-107}

\section{Thorsten Hens ${ }^{1}$, Vahit Ferhan Benli ${ }^{2}$}

${ }^{1}$ University of Zurich, Department of Banking and Finance, Zurich, Switzerland.

Thorsten.Hens@bf.uzh.ch, ORCID: 0000-0002-0266-1561

${ }^{2}$ Istanbul Commerce University, Banking and Finance Department, istanbul, Turkey.

vfbenli@ticaret.edu.tr , ORCID: 0000-0002-0510-7662

\section{To cite this document}

Thorsten, H.,Benli, V. F. (2021). Behavioral finance in the era of Covid-19. PressAcademia Procedia (PAP), 14, 106-107.

Permanent link to this document: http://doi.org/10.17261/Pressacademia.2021.1496

Copyright: Published by PressAcademia and limited licensed re-use rights only.

\begin{abstract}
Purpose- Traditional finance has focused on the ideal scenario of thorougly rational investors in efficient markets. Accordingly, the market remains efficient even if some investors behave irrationally. In practice however, we observe that even professional investors behave irrationally and may decide under behavioral biases. Moreover, in efficient markets the mean-variance optimisation is no longer rational. Behavioral Finance gives more attention to the investor's behavior.This newly designated "investor"dislikes losses more than volatility, reacts more to losses than gains and reveals different type of risk profiles. Consequently, this investor invests differently during the Covid-19 era than the theoretical investor in the traditional decision theory. In this context, the purpose of this paper is to make investors aware of the typical behavioral biases they fall prey to in times of market crashes. Surrounded with different type of biases, we can observe and experience that investors are human beings whose decisions might be driven by emotions or misunderstandings and they might use heuristics to handle information and make investment decisions. They might buy an asset when it is expensive and sell it whey it is cheap as the model of a "roller coaster".

Methodology- We will be relying our research to the foundations of behavioural finance, namely the decision theory. Decision theory has three broad paradigms: expected utility theory, prospect theory and mean-variance analysis. Expected utility theory clarifies which decisions are rational, prospect theory describes which decisions are most often observed, and mean-variance analysis is the best known decision model in practice. To more deeply understand why we may observe such behaviour, we consider a typical decision-making process and discuss how each stage of the process can be biased. Based on interesting findings of recent literature analysing individual and market behaviour during the COVID-19 stock market crash we suggest a model that describes these findings along the roller coaster of emotions during stock market cycles.

Findings- The coronavirus has a severe impact on all major asset classes. A naive investor was falling prey of many behavioral biases. Monetary and fiscal policy can only cure symptoms. Severe restrictions and medical advances were needed to fight it. We are almost through this crisis but some other crises will also happen. We find adapative behavior, panic selling and regret on the level of individual investors as well as overreaction on the level of the market and probability matching biases. We found that people react to a high randomness in a stochastic process with high activity and market timing in high volatility is impossible to exercise for investors.

Conclusion- The COVID 19 crisis was a typical market crash. One of the major macro conclusions is the fact that the FED and the other central banks cannot fight against the coronavirus while burning massive amounts of cash in an "infected market". This is the point where the monetary policy based investments could not be taken under loop. In an infected market you observe an "Illusion of Control". The investors would think that everything would be under "control" even though the markets were showing higher volatilities. Contrary to the fundamental investment theories where people would rest and slow down the investment activities during higher volatility, the behavioral investor would find himself in a more stochastic investment process with higher volumes of investment and/or disinvestment activities. Consequently, it is important to learn from it so that investors avoid behavioural biases in the next stock market crash.
\end{abstract}

Keywords: Behavioral finance, Covid 19, Incomplete Markets, Financial Crisis, Criteria for Decision-Making under Risk and Uncertainty, Portfolio Choice, Investment Decisions, Evalutionary Finance

JEL Codes: D52, D81, D83, G11, G01, B52 


\section{REFERENCES}

Andries, A.M, Ongena, S., Sprincean, N. (2021). The COVID-19 Pandemic and Sovereign Bond Risk. The North American Journal of Economics and Finance, Volume 58, 01527, ISSN 1062-9408.

Bachmann, K., De Giorgi, E., Hens, T. (2018). Behavioral Finance for Private Banking, From the Art of Advice to the Science of Advice, $2^{\text {nd }}$ ed., Wiley.

Hameleers, M. (2021). Prospect Theory in Times of a Pandemic: The Effects of Gain versus Loss Framing on Risky Choices and Emotional Responses during the 2020 Coronavirus Outbreak - Evidence from the US and the Netherlands, Mass Communication and Society, 24:4, 479499.

Mdaghri, A.A., Raghibi, A., Thanh, C.N., Oubdi, L. (October 2020). Stock market liquidity, the great lockdown and the Covid-19 global pandemic nexus in MENA countries, The Review of Behavioral Finance, Emerald Publishing,Volume 13, No. 1, pp. 51-68.

Mnif, E., Jarboui, A. (2021). COVID-19, bitcoin market efficiency, herd behaviour, Review of Behavioral Finance, Emerald Publishing, Vol. 13, No. 1, pp. 69-84.

Ramelli, S., Wagner, A.F. (November 2020). Feverish Stock Price Reactions to COVID-19, The Review of Corporate Finance Studies, Volume 9, Issue 3, Pages 622-655.

Shahabi, V., Azar, A., Razi, F.F., Shams, S. (2020), Simulation of the effect of COVID-19 outbreak on the development o branchless banking in Iran: case study of resalat Qard-al- Hasan Bank, Review of Behavioral Finance, Emerald Publishing, Vol. 13, No. 1, 2021, pp. 85-108.

Smales, A. L. (2021). Investor attention and the reponse uf US stock market sectors to the COVID-19 crisis, Review of Behavioral Finance, Emerald Publishing, Vol. 13, No. 1, pp. 20-39.

Subramaniam, S., Chakraborty, M. (2021). COVID-19 fear index: does it matter for stock market returns ?, Review of Behavioral Finance, Emerald Publishing, Vol. 13, No. 1, pp. 40-50.

Wagner, A.F. (May 2020). What the stock market tells us about the post-COVID-19 world?. Nature Human BeHaviour, Vol. 4, May 2020, p. 440.

Wookjae, H., Grable, J. E., Rabbani, A.G. (2020). A test of the association between the initial surge in COVID-19 cases and subsequent changes in financial risk tolerance, Review of Behavioral Finance, Emerald Publishing, Vol. 13, No. 1, 2021, pp. 3-19.

Vasileiou, E. (2021). Behavioral finance and market efficiency in the time of the COVID-19 pandemic: does fear drive the market?, International Review of Applied Economics, 35:2, 224-241. 